\title{
Selected metabolic aspects of elastin and collagen fiber proteolysis in diseases of the respiratory system - the significance of a1 antitrypsin deficiency
}

\author{
Agata Dżeljilji1 ${ }^{1}$, Wojciech Rokicki² ${ }^{2}$ Krzysztof Karuś ${ }^{3}$ \\ ${ }^{1}$ National Institute of Tuberculosis and Lung Diseases, Warsaw, Poland \\ ${ }^{2}$ Department of Thoracic Surgery, School of Medicine with the Division of Dentistry in Zabrze, Medical University of Silesia \\ in Katowice, Poland \\ ${ }^{3}$ Center of Pulmonology and Thoracic Surgery, Bystra, Poland
}

Kardiochirurgia i Torakochirurgia Polska 2016; 13 (3): 242-247

\begin{abstract}
The process of elastin and collagen fiber destruction was presented based on the example of the changes taking place in the course of chronic obstructive pulmonary disease and primary spontaneous pneumothorax. In 1963, when analyzing patients with $\alpha 1$ antitrypsin deficiency, Dr Laurell and Dr Eriksson hypothesized that elastolysis plays a role in the pathogenesis of emphysema, which marked the beginning of studies aimed at analyzing this process. The present work concerns new scientific reports regarding the hypothesis. The most important risk factors include protease-antiprotease imbalance and $\alpha 1$ antitrypsin protein deficiency.
\end{abstract}

Key words: $\alpha 1$ antitrypsin, protease-antiprotease imbalance.

\section{Introduction}

Alpha-1 antitrypsin (AAT) is a potent antiprotease protecting lung tissue from the destructive influence of proteolytic enzymes. It is estimated that emphysema is caused by congenital AAT deficiency in $1-5 \%$ of cases [1], but no precise data are available. Full verification of an AAT deficiency diagnosis is only possible at the molecular level. The AAT protein is encoded by the SERPINA 1 gene, located on the long arm of chromosome 14 (14q32.1). Over 130 variants of AAT have been identified to date (Tab. I), the normal variant being PiMM. The main deficiency phenotypes causing severe AAT deficiency were labeled as PiMS, PiMZ, PiSZ, PiSS, and PiZZ. The occurrence of spontaneous pneumothorax is often the first symptom of AAT deficiency. The AAT deficiency is conducive to recurrent pneumothorax. Lin et al. presented a case of a 33-year-old pilot with pneumothorax as the first symptom of AAT protein deficiency. The AAT blood concentration was also significantly lowered, and further molecular diagnostics pointed to a mutation in the SERPINA 1 gene; the PiZZ genotype was established [2].

\section{Streszczenie}

Proces destrukcji włókien elastynowych i kolagenowych został przedstawiony na przykładzie zmian $\mathrm{w}$ przebiegu przewlekłej obturacyjnej choroby płuc i samoistnej pierwotnej odmy opłucnowej. W 1963 r. Laurell i Eriksson, analizując chorych z niedoborem $\alpha 1$ antytrypsyny, zaproponowali hipotezę elastolityczną w patomechanizmie rozedmy płuc. Był to początek badań, których cel stanowiła analiza tego procesu. Pracę poświęcono nowym doniesieniom naukowym dotyczącym hipotezy elastolitycznej. Do najistotniejszym czynników ryzyka należy m.in. zaburzenie równowagi proteazowo-antyproteazowej oraz niedobór białka $\alpha 1$ antytrypsyny.

Słowa kluczowe: $\alpha 1$ antytrypsyna, zaburzenie równowagi proteazowo-antyproteazowej.

Sotcan et al. described a case of a 40-year-old woman, who was a tobacco smoker suffering from chronic obstructive pulmonary disease (COPD). Blood AAT was $72 \mathrm{mg} / \mathrm{dl}$ (laboratory norms: 200-300 mg/dl) [3]. Miravitlles et al. presented the results of enhanced diagnostics conducted in a 39-year-old woman, who was a former tobacco smoker (8 pack-years) with early-onset emphysema. A new variant of the AAT protein was found - YBARCELONA - PIYM. During a 6-year follow-up, no deterioration (clinical or radiological) occurred in the patient, who refrained from smoking tobacco in that period [4]. Early diagnosis of AAT deficiency can improve the patients' quality of life and extend their survival.

\section{Protease-antiprotease imbalance}

Excessive proteolysis leads to the destruction of elastin and collagen fibers, which causes the restructuring of the respiratory tract. Higher activity of matrix metalloproteinases MMP-1, MMP-2, MMP-8, MMP-9, and MMP-12 originating from inflammatory cells, serine proteases (neutrophil elas-

Address for correspondence: Agata Dżeljilji MD, National Research Institute of Tuberculosis and Lung Diseases, 26 Płocka St, 01-138 Warsaw, Poland, phone: +48 668376 010, e-mail: nosearmy85@gmail.com

Received: 15.01.2015, accepted: 16.08.2016. 


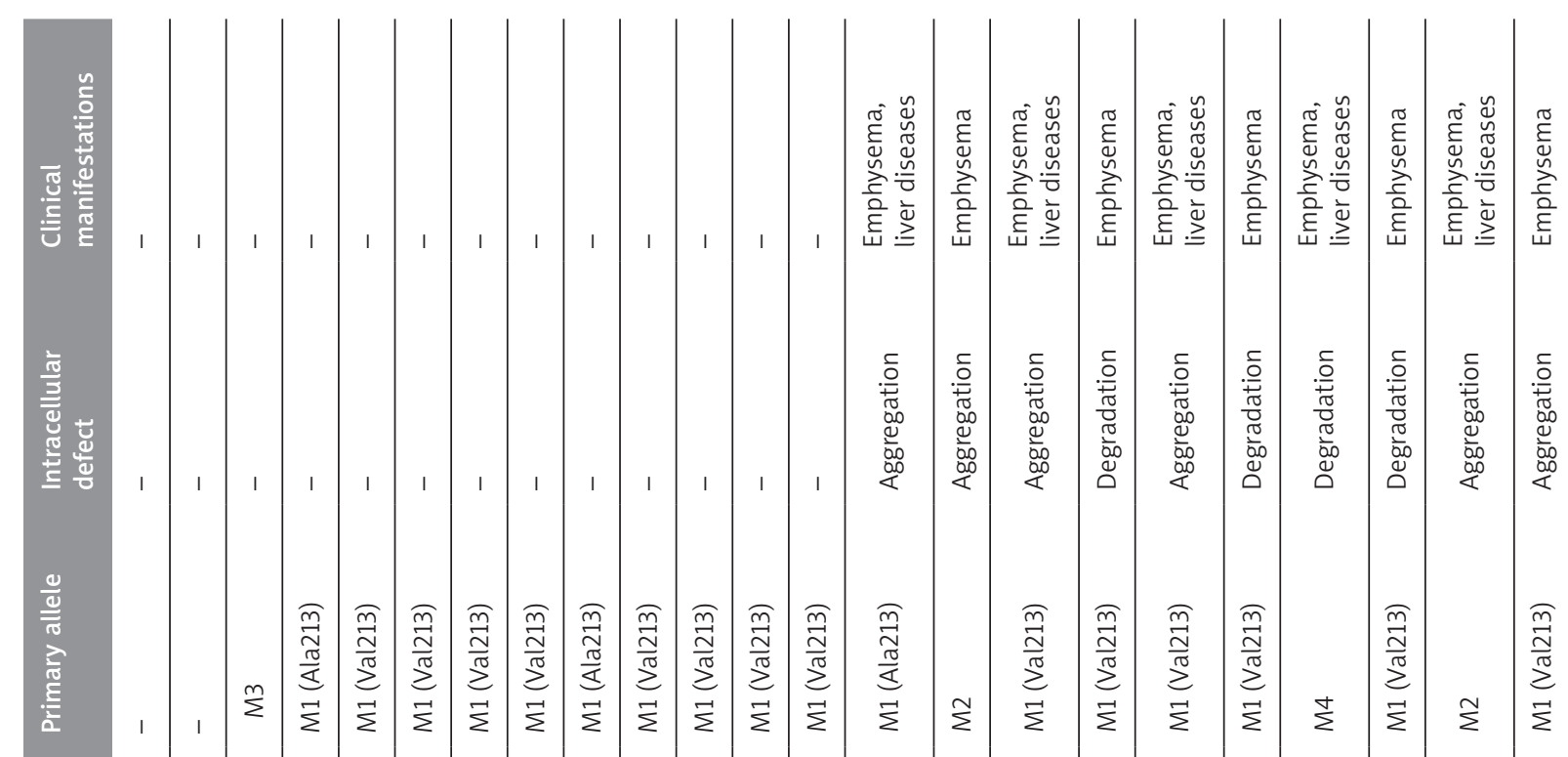

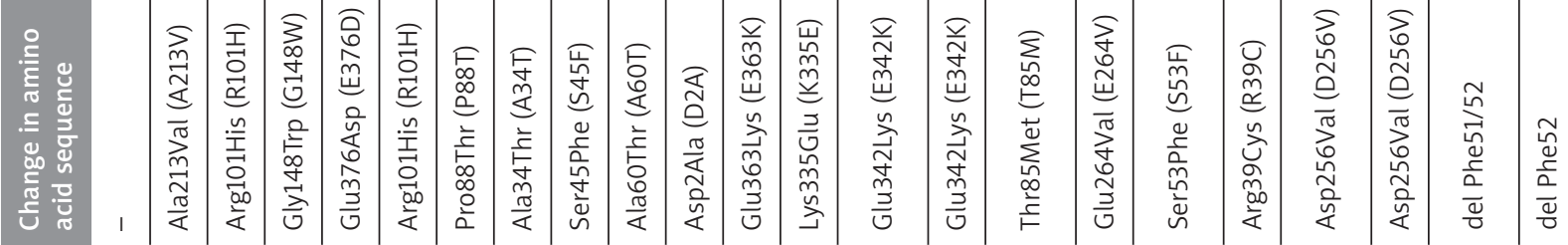

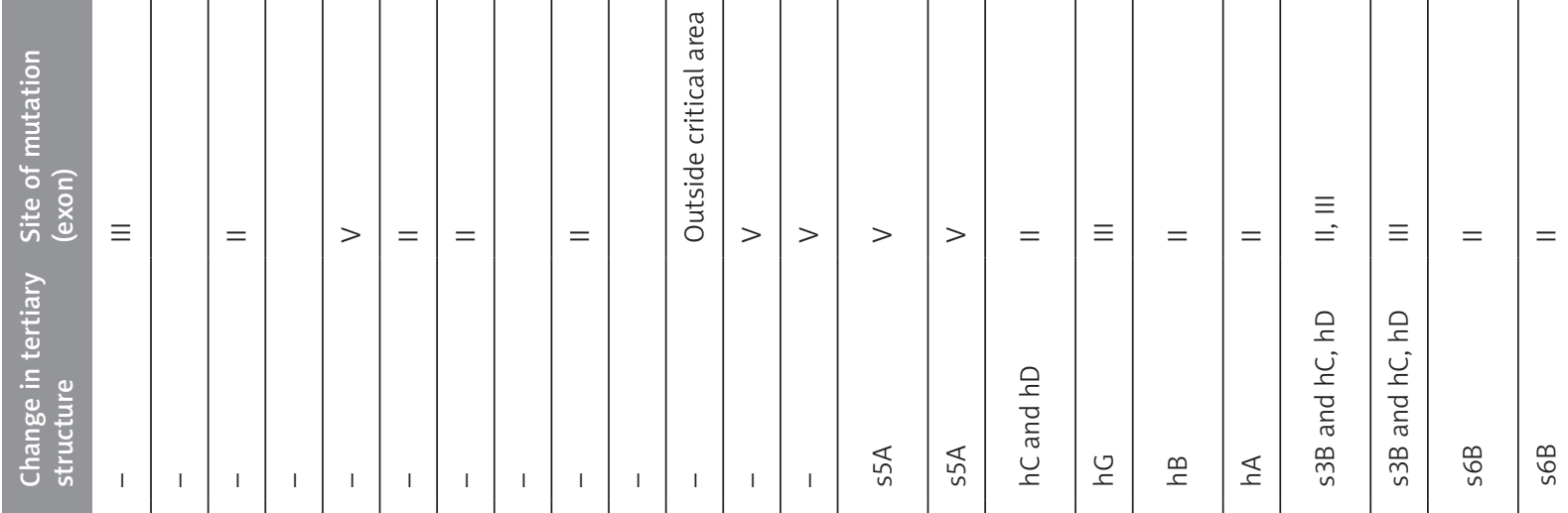

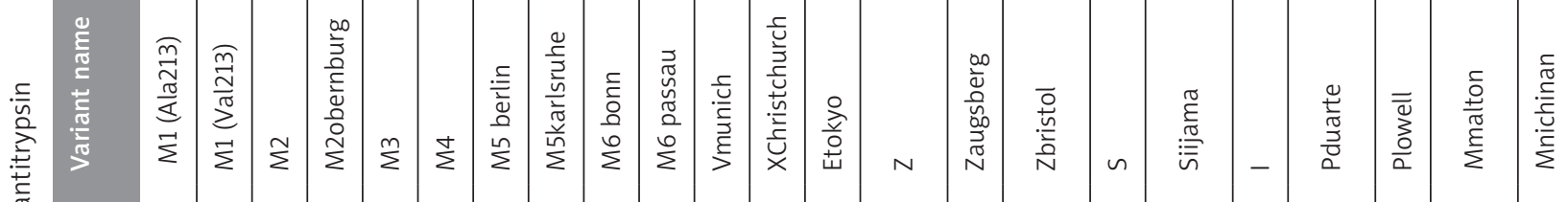

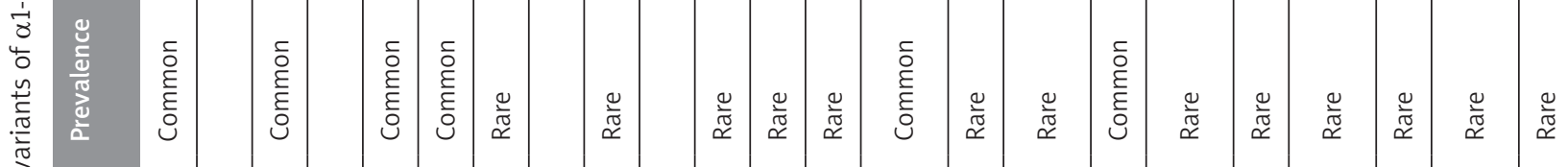

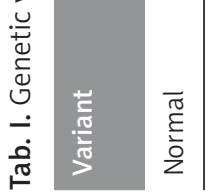




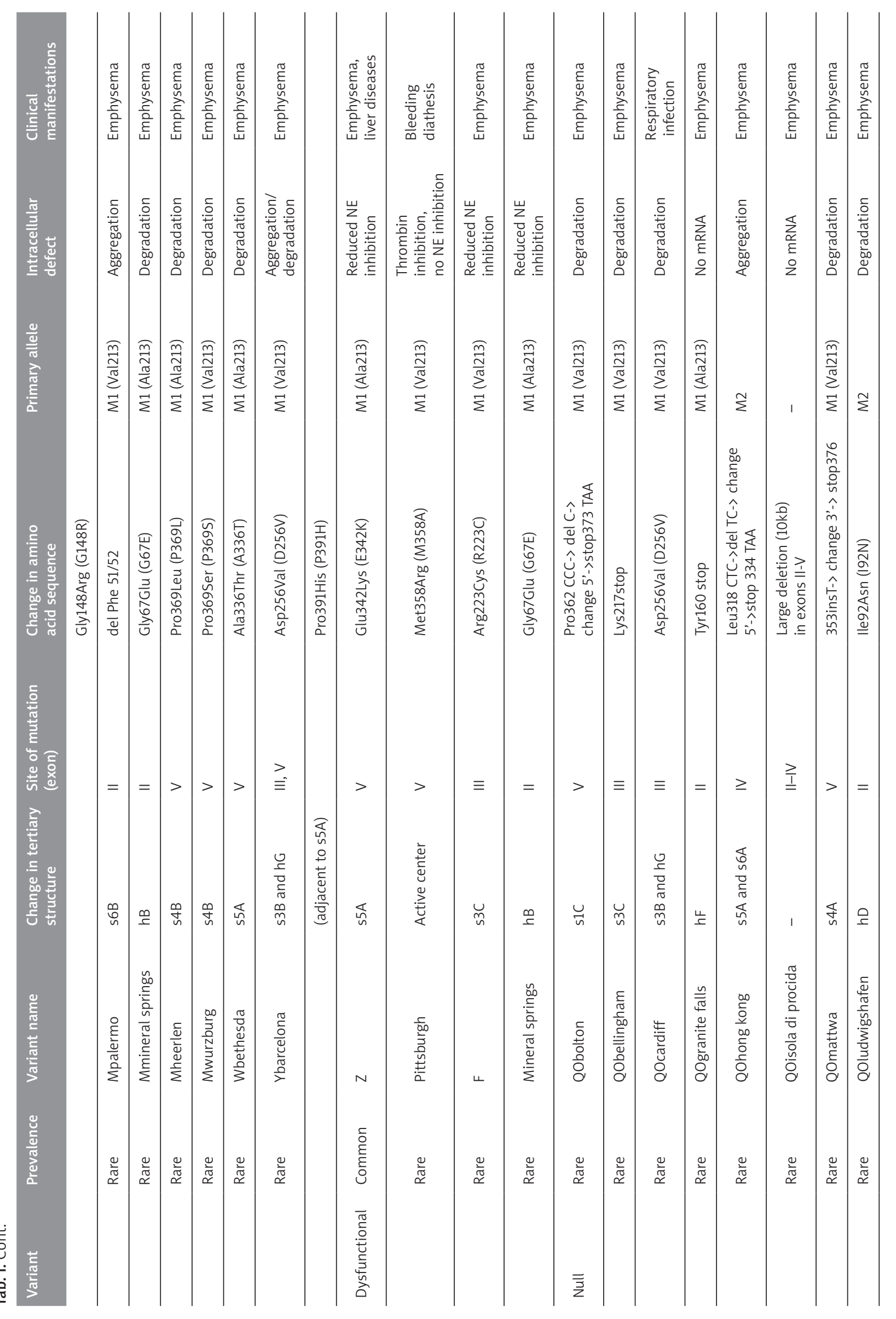


tase, cathepsin G, and proteinase 3), and enzymes of CD8+ T-cells (perforin and granzyme) was found in patients with emphysema [5]. Elastin and collagen degradation, however, can also take place with the participation of other serine and cysteine proteases as well as cathepsins. Protease-antiprotease imbalance and loss of elastic recoil occur when the increase in the activity of proteolytic enzymes is accompanied by a quantitative or qualitative deficiency of antiproteases: AAT, secretory leukocyte protease inhibitor (SLPI), tissue inhibitor of metalloproteinases (TIMP), and others.

\section{Importance of $\alpha 1$ antitrypsin}

In patients with normal AAT concentrations, emphysematous lesions are most frequently located in the upper sections of the lungs; as a result, the lower lung areas are characterized by higher perfusion and, consequently, broader distribution of antiproteases. On the other hand, in patients with AAT deficiency, lesions of the highest severity occur in the lower regions of the lungs, which is associated with higher concentrations of neutrophils supplied together with blood [6].

Alpha-1 antitrypsin owes its name to an initial theory, according to which its main antagonist was trypsin (serine protease). It is now known that the scope of its activity is much wider, and the literature also uses the name $\alpha 1$ antiprotease. Its physiological activity is based on antiprotease properties towards proteolytic enzymes, especially neutrophil elastase, but also protease-3, myeloperoxidase, cathepsin G, serine proteases (trypsin, kallikrein 7 and 14, urokinase, granzyme $B$, tryptase, chymase, matriptase), cysteine proteases (caspase-1 and -3, calpain 1), and ADAM-17 (also known as TACE, tumor necrosis factor- $\alpha$-converting enzyme) [7].

Alpha- 1 antitrypsin is a glycoprotein with a molecular mass of $55 \mathrm{kDa}$, built of a single polypeptide chain and three oligosaccharide chains (Fig. 1). It belongs to the class of acute-phase proteins and plays an important role in maintaining protease-antiprotease balance. Epidemiological research confirms a relationship between AAT deficiency and the development of chronic lung diseases. The AAT synthesis takes place mainly in the liver, but is also observed in neoplastic cells.

Neutrophil elastase constitutes the main proteolytic mechanism in patients with AAT deficiency [8]. Secretory leukocyte protease inhibitor (SLPI) has a lower affinity to elastase than AAT and constitutes only $20 \%$ of the antiproteolytic activity of antitrypsin. Physiologically, the half-life of free elastase is $0.6 \mathrm{~ms}$, which is followed by its uptake and inactivation by protease inhibitors. When the proteaseantiprotease balance is disrupted, this time is extended, and elastase remains outside the cell longer in its free form. Alfa-1 antiprotease contains 394 amino-acid residues, with active position 358 occupied by methionine. The AAT inactivates elastase by irreversibly binding with methionine. The AAT inhibitor binds with a neutrophil elastase molecule at a $1: 1$ ratio. The resulting inactive AAT : NE complex diffuses into the blood; its half-life is approximately 1 hour. Position 358 in an AAT molecule is susceptible to oxidant attacks.
Methionine oxidation inactivates AAT, leading to its proteolytic degradation. The purpose of this mechanism may be to protect elastase when its high activity is required.

\section{Epidemiology}

Alpha-1 antitrypsin deficiency is a significant clinical problem. It is estimated that AATD, like cystic fibrosis and Down syndrome, is one of the most frequent genetic disorders found in the Caucasian race. The average age of patients diagnosed with AAT deficiency is $54.6(\mathrm{SD}=13.2)$ years, but it is important to point out that in the group of patients with the PiZZ variant it is $49.4(S D=14.5)$ years [9-11]. The available data suggest that severe homozygous AAT deficiency (PiZZ) in Europe is more frequent in Scandinavian countries (allele frequency $2.3 \%$ ) than in the south of the continent (allele frequency 1.0\%), 1 in 4727 Caucasian neonates in Europe on average. Poland is one of the few European countries that does not have complete data on the prevalence of AATD $[12,13]$. Research in this field started in Poland during the 1970s. Diagnostic procedures were conducted in a group of 3560 healthy individuals. A starch gel electrophoresis method was used for phenotype assessment; it is no longer used due to its low sensitivity. The following results were obtained: prevalence of PiZ - 1.4/1000 and PiS - 15.6/1000 [14]. The research was resumed in the 1990s, but it mainly focused on two regions of the country: Małopolska and Wielkopolska. The size of individual groups ranged between 423 and 859 subjects. The average estimated prevalence of $\mathrm{PiZ}$ and $\mathrm{PiS}$ was, respectively, 14.5/1000 and 10.9/1000 and of PiZZ - 1.9110 in a group of 2653 individuals studied with very diverse laboratory methods [15-19]. The results were significantly different from the data obtained 20 years earlier. Information concerning the deficiency phenotypes is recorded in a European register of patients with AAT deficiency (Alpha- 1 International Registry). In 2010, a Polish register of patients with the deficiency was created; it is maintained by the Department of Genetics and Clinical Immunology at the Warsaw Institute of Tuberculosis and Lung Diseases.

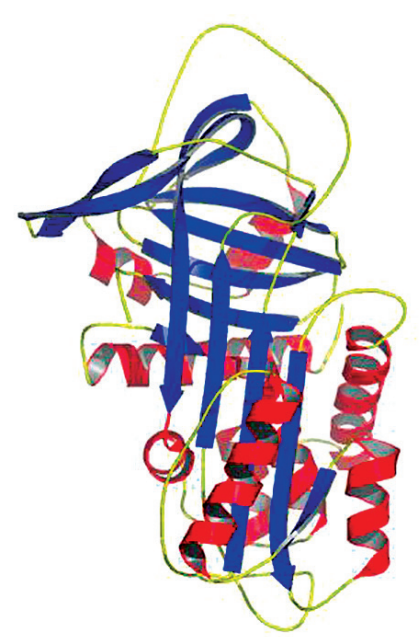

Fig. 1. Structure of an $\alpha 1$ antitrypsin protein molecule 


\section{Diagnostics}

\section{Indications for diagnostics}

Epidemiological research confirms a relationship between AAT deficiency and the development of chronic lung diseases. An analysis conducted by the Canadian Thoracic Society (CTS) enabled the identification of the group of patients with high risk of AATD. According to the CTS, diagnostics should be conducted among patients with COPD diagnosed $<65$ years of age and/or a smoking history of $<20$ pack-years [20-27]. The common guidelines of the American Thoracic Society (ATS) and the European Respiratory Society (ERS) recommend that AATD diagnostics should be conducted in patients with respiratory diseases in the case of: early-onset emphysema (< 45 years of age), emphysema not associated with smoking tobacco or environmental factors, and bronchiectasis of unclear etiology [28].

\section{Diagnostic methods}

Full verification of an AAT deficiency diagnosis and confirmation of the results of quantitative determination are only possible at the molecular level. In the case of AAT deficiency, such verification can only be provided by identifying the phenotype or genotype of the inhibitor. Isoelectric focusing is a widely used method for identifying AAT variants, facilitating the establishment of the type of the circulating AAT protein (phenotype). An alternative to this method is DNA analysis. The presence of a mutation in locus Pi responsible for the deficiency can be established directly with genetic tests $[29,30]$. During the last two decades, the methods for identifying a genetic AAT deficit became simplified. Another unique achievement is the implementation of a test that enables the analysis of AAT concentration in several drops of blood collected on filter paper.

\section{When to collect the material}

Alpha-1 antitrypsin blood concentration is subject to fluctuations and may increase significantly during an inflammatory response (even 3 - to 11-fold) and, to a lesser extent, during pregnancy and the use of oral hormonal contraception. In order to exclude an increase of acute-phase proteins resulting from tissue damage or an inflammatory response, it is necessary to additionally determine the concentration of C-reactive protein in the collected samples. The material should not be collected during treatment for pneumothorax, in the early postoperative period, or if features of infection are revealed.

\section{Alpha-1 antitrypsin deficiency}

Over 130 variants of AAT protein have been identified so far (Tab. I); they were divided into 4 classes, depending on the concentration and function of the protein in plasma. The first class includes $\mathrm{M}$-allele proteins, constituting the most frequent variant in the Polish population (PiM1M1 homozygotes constitute $55 \%$ of all phenotypes, while PiM1M2 and PiM1M3 heterozygotes constitute from $5 \%$ to $10 \%$ ). This variant ensures the proper functioning of
AAT in plasma. The second class includes deficiency variants, which were defined as protein products accumulating inside cells or undergoing degradation in the liver. The most common deficiency alleles are $\mathrm{Z}$ and $\mathrm{S}$.

The homozygous PiZZ variant is characterized by a protein concentration approximately $85 \%$ lower than that encountered in individuals with the normal PiMM genotype; it is associated with the most severe clinical manifestations of AAT deficiency. In turn, PiSS homozygotes exhibit approximately $40 \%$ lower AAT concentrations in comparison to healthy individuals. The PiSS variant as well as the heterozygous PiMS and PiMZ variants ensure normal inhibitor function in plasma. It is, however, important to note that smoking tobacco significantly influences the intensity of proteolysis. The combination of nicotinism and AAT concentrations below $40 \%$ of normal is associated with an increased risk of respiratory diseases. The third class is composed of null alleles (PiQO), resulting from the premature discontinuation of translation, partial deletion of a gene, or intracellular protein degradation. Consequently, they are not detectable in plasma. The rare QOgranite falls, QObellingham, and QOmattawa mutations may serve as examples. The last, fourth class is constituted by dysfunctional variants, which may not only be associated with the loss of physiological activity, but may also acquire new enzymatic properties through a specific mutation. The Pittsburgh protein is an example of a protein product that does not contain methionine in the active position for neutrophil elastase and loses the ability to block it. In plasma, however, it acts as a strong anticoagulant, leading to bleeding diathesis. Anomalies of the AAT protein underlie numerous pathologies of both local and systemic nature [31].

\section{Surgical treatment of patients with $\alpha 1$ antitrypsin deficiency}

According to a report published in 1995 by the International Society for Heart and Lung Transplantation, 12\% of lung transplants were conducted due to advanced emphysema resulting from AAT deficiency [32]; 5-year survival was approximately 50\% [33]. In later years (1995-2014), patients with AAT deficiency constituted $5.4 \%$ of lung transplant recipients $(n=2459)$, and the average survival was 6.5 years. Transplant failures may be influenced by the following factors: exacerbation of inflammatory response and release of acute-phase proteins as a result of injury associated with the invasive surgical procedure, lack of clear recommendations for the use of supplement therapy before and after the transplant, as well as the natural course of the disease. In a prospective study, Cassina et al. evaluated the results of surgical treatment after bilateral lung volume reduction surgery (LVRS) in patients with confirmed AAT deficiency $(n=12)$ and emphysema associated with long-term tobacco smoking $(n=18)$. The assessment of respiratory capacity was conducted in both groups, including the results of 6-minute walk tests, respiratory mechanics, and arterial blood gas. The parameters in both 
groups were statistically insignificant with the exception of forced expiratory volume in $1^{\text {st }}$ second $\left(\mathrm{FEV}_{1}\right)$, which was lower in the group of patients with AAT deficiency (24\% vs. $31 \%, p<0.05)$. After the procedures, both groups exhibited a significant improvement in respiratory capacity. However, in the group of AAT deficient patients, the measured parameters returned to preoperative levels after a period of 6-12 months and deteriorated significantly within 24 months [34].

\section{Conclusions}

Smoking tobacco plays a significant role in the natural course of the disease.

In patients with AAT deficiency, this factor quickens the onset of the first clinical symptoms and is associated with the development of the severe form of the disease. Early emphysema requires enhanced diagnostics.

Alpha-1 antitrypsin deficiency is not a key issue in patients at risk of spontaneous pneumothorax, but it may constitute a significant burden leading to progressive degeneration of lung tissue [35-37]. The above data demonstrate the complexity of the discussed issue and point to the need for early diagnosis of AAT deficiency in risk groups, especially in patients qualified for surgical procedures.

\section{Disclosure}

\section{Authors report no conflict of interest.}

\section{References}

1. Abboud RT, Ford GT, Chapman KR, Standards Committee of Canadian Thoracic Society. Alpha-1 antitrypsin deficiency: a position statement of Canadian Thoracic Society. Can Respir J 2001; 8: 81-88.

2. Lin Y, Chiu WK, Chang H, Cheng YL, Chen JC. Spontaneous pneumothorax in flight as first manifestation of alpha-1 antitrypsin deficiency. Aviat Space Environ Med 2008; 79: 704-706.

3. Sotcan M, Copaci I, Enache M, Jurcuț C, Duțescu V, Rusu C. A rare case of pulmonary emphysema. Rom J Intern Med 2006; 44: 465-470.

4. Miravitlles M, Vila S, Jaroli R, de la Roza C, Rodriguez- Friaz F, Vidal R. Emphysema due to alpha- antitrypsin deficiency: familial study of the YBARCELONA variant. Chest 2003; 124: 404-406.

5. Barnes PJ. Mechanisms of COPD: Differences from asthma. Chest 2000; 177 (2 Suppl): 10S-14S.

6. Tomashefski J Jr, Cagle P, Farver C, Fraire A. Dail and Hammar' s Pulmonary Pathology. Vol. I, Nonneoplastic Lung Disease. Third edition, Springer, New York 2008.

7. Chorostowska-Wynimko J, Popławska B, Janciauskiene S. Alfa-1 antytrypsyna: rola w fizjologii i patologii człowieka. Int Rev Allergol Clin Immunol Family Med 2012; 18: 22-28.

8. Roszkowska-Jakimiec W, Worowska A, Gacko M, Maksimowicz T. Proteazy granulocytów obojętnochłonnych. Post Hig Med Dośw 2002; 56: 73-92.

9. Blanco I, de Serres FJ, Fernandez-Bustillo E, Lara B, Miravitlles M. Estimated numbers and prevalence of $\mathrm{PI}^{\star} \mathrm{S}$ and $\mathrm{PI}^{\star} \mathrm{Z}$ alleles of a1-antitrypsin deficiency in European countries. Eur Respir J 2006; 27: 77-84.

10. Luisetti M, Seersholm N. Alpha1-antitrypsin deficiency. 1: epidemiology of alpha-1-antitrypsin deficiency. Thorax 2004; 59: 164-169.

11. Piras B, Ferrarotti I, Lara B, Martinez MT, Bustamante A, Ottaviani S, Pirina P, Luisetti M, Miravitlles M. Clinical phenotypes of Italian and Spanish patients with alpha-1 antitrypsin deficiency. Eur Respir J 2013; 42: 54-64.

12. Chorostowska-Wynimko J, Struniawski R, Sliwinski P, Wajda B, CzajkowskaMalinowska $M$. The national alpha-1 antitrypsin deficiency registry in Poland. COPD 2015; 12 (Suppl 1): 22-26.

13. Kohnlein T, Janciauskiene $\mathrm{S}$, Welte T. Diagnostic delay and clinical modifiers in alpha-1 antitrypsin deficiency. Ther Adv Respir Dis 2010; 4: 279-287.
14. Opolska B. Badania nad częstością występowania fenotypów układu PI w populacji Polski południowej. Przegl Lek 1974; 31: 851-854.

15. Kaczor MP, Sanak M, Libura-Twardowska M, Szczeklik A. The prevalence of alpha-1 antitrypsin deficiency in a representative population sample from Poland. Respir Med 2007; 101: 2520-2525.

16. Titenko-Holland NV, Kowalska A. Alpha-1 antitrypsin (PI) subtypes in Russians and Poles. Hum Hered 1992; 42: 384-386.

17. Kowalska A, Rujner J. Polimorfizm locus PI (alpha-1 antitrypsin) u mieszkańców województwa poznańskiego. Pol Tyg Lek 1994; 49: 195-197.

18. Walter H, Danker-Hopfe $\mathrm{H}$, Lemmermann M, Lorenz $\mathrm{M}$. Investigations on the variability of four genetic serum protein markers in Poland. Z Morphol Anthropol 1992; 79: 203-214.

19. Kowalska A, Rujner J, Titenko-Holland NV, Pilacik B. Alpha-1-antitrypsin subtypes in Polish newborns. Hum Hered 1995; 45: 351-354.

20. Sørheim IC, Bakke P, Gulsvik A, Pillai SG, Johannessen A, Gaarder PI, Campbell EJ, Agustí A, Calverley PM, Donner CF, Make BJ, Rennard SI, Vestbo J, Wouters EF, Paré PD, Levy RD, Coxson HO, Lomas DA, Hersh CP, Silverman EK. Alpha-1 antitrypsine protease inhibitor $M Z$ heterozygosity is associated with airflow obstruction in two large cohorts. Chest 2010; 138: 1125-1132.

21. Wencker M, Marx A, Konietzko N, Schaefer B, Campbell EJ. Screening for alpha-1-Pi deficiency in patients with lung diseases. Eur Respir J 2002; 20: 319-324.

22. Seersholm N, Wilcke JT, Kok-Jensen A, Dirksen A. Risk of hospital admission for obstructive pulmonary disease in alpha(1)-antitrypsin heterozygotes of phenotype PiMZ. Am J Respir Crit Care Med 2000; 161: 81-84.

23. Eden E, Holbrook JT, Brantly ML, Turino GM, Wise RA. Prevalance of alpha-1 antitrypsin deficiency in poorly controlled astma - results from the ALA-ACRC low dose theophylline trial. J Asthma 2007; 44: 605-608.

24. Van Veen IH, ten Brinke A, van der Linden AC, Rabe KF, Bel EH. Deficient alpha-1 antitrypsin phenotypes and persistent airflow limitation in severe asthma. Respir Med 2006; 100: 1534-1539.

25. Sansom ME, Ferry BL, Sherrel ZP, Chapel HM. A preliminary assessment of alpha-1 antitrypsin $\mathrm{S}$ and $\mathrm{Z}$ deficiency allele frequencies in common variable immunodeficiency patients with and without bronchiectasis. Clin Exp Immunol 2002; 130: 489-494.

26. Cuvelier A, Muir JF, Hellot MF, Benhamou D, Martin JP, Bénichou J, Sesboüé R. Distribution of alpha(1)-antitrypsin alleles in patients with bronchiectasis. Chest 200; 117: 415-419.

27. Marciniuk DD, Hernandez P, Balter M, Bourbeau J, Chapman KR, Ford GT, Lauzon JL, Maltais F, O'Donnell DE, Goodridge D, Strange C, Cave AJ, Curren K, Muthuri S; Canadian Thoracic Society COPD Clinical Assembly Alpha-1 Antitrypsin Deficiency Expert Working Group. Alpha-1 antitrypsin deficiency targeted testing and augmentation therapy: a Canadian Thoracic Society clinical practice quideline. Can Respir J 2012; 19: 109-116.

28. American Thoracic Society, European Respiratory Society Statement: standards for the diagnosis and management of individuals with alpha-1 antitrypsin deficiency. Am J Respir Crit Care Med 2003; 168: 818-900.

29. Fadeel B, Xue D, Kagan V. Programmed cell clearance: molecular regulation of the elimination of apoptotic cell corpes and its role in the resolution of inflammation. Biochem Biophys Res Commun 2010; 396: 7-10.

30. Feghali-Bostwick CA, Gadgil AS, Otterbein LE, Pilewski JM, Stoner MW, Csizmadia E, Zhang Y, Sciurba FC, Duncan SR. Autoantibodies in patients with chronic obstructive pulmonary disease. Am J Respir Crit Care Med 2008; 177: 156-163.

31. Popławska B, Janciauskiene S, Chorostowska-Wynimko J. Genetyczne warianty alfa-1 antytrypsyny: klasyfikacja i znaczenie kliniczne. Pneumonol Alergol Pol 2013: 81: 45-54

32. Hosenpud JD, Novick RJ, Breen TJ, Keck B, Daily P. The Registry of the International Society for Heart and Lung Transplantation: twelfth official report. J Heart Lung Transplant 1995; 14: 805-815.

33. Levine SM, Anzueto A, Peters II, Cronin T, Sako EY, Jenkinson SG, Bryan CL Medium term functional results of single-lung transplantation for end stage obstructive lung disease. Am J Respir Crit Care Med 1994; 150: 398-402.

34. Cassina PC, Teschler H, Konietzko N, Theegarten D, Stamatis G. Two-year results after lung volume reduction surgery in alpha-1 antitrypsin deficiency versus smoker's emphysema. Eur Respir J 1998; 12: 1028-1032.

35. Stoller JK, Sandhaus RA, Turino G, Dickson R, Rodgers K, Strange C. Delay in diagnosis of a1-antitrypsin deficiency: a continuing problem. Chest 2005; 128: 1989-1994.

36. Travis J, Salvesen GS. Human plasma proteinase inhibitors. Ann Rev Biochem 1983; 52: 655-709.

37. Stockley RA. Alpha-1-antitrypsin deficiency. What next? Thorax 2000; 55: 614-618. 